\title{
The Influence Of Service Quality And Customer Satisfaction Towards Customer Loyalty At Bank Mega Syariah Bengkulu
}

\section{Pengaruh Kualitas Pelayanan Dan Kepuasan Nasabah Terhadap Loyalitas Nasabah Pada Bank Mega Syariah Bengkulu}

\author{
Afif Fakhri Pahlevi'); Suwarni²); Nurzam²) \\ ${ }^{1)}$ Study Program of Management Faculty of Econimic, Universitas Dehasen Bengkulu \\ 2) Department of Management, Faculty of Economic, Universitas Dehasen Bengkulu \\ Email: ${ }^{1)}$ Afifp133@gmail.com ; ${ }^{2)}$ Suwarni.h.13@unived.ac.id ; ${ }^{3)}$ trisnanurzam@gmail.com
}

How to Cite:

Pahlevi, F. A., Suwarni., Nurzam. (2021). The Influence Of Service Quality And Customer Satisfaction Towards Customer Loyalty At Bank Mega Syariah Bengkulu. Jurnal Ekonomi Manajemen Akuntansi Dan Keuangan, 2(4). DOI: https://doi.org/10.53697/emak.v2i4

ARTICLE HISTORY

Received [12 Agust 2021]

Revised [25 Agust 2021]

Accepted [05 October 2021]

KEYWORDS

Service Quality, Customer Satisfaction, Customer Loyalty

This is an open access article under the $C C-B Y$-SA license

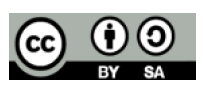

\section{ABSTRAK}

Tujuan penelitian ini adalah untuk mengetahui pengaruh kualitas pelayanan dan kepuasan nasabah terhadap loyalitas nasabah pada Bank Mega Syariah Bengkulu. Sampel dalam penelitian ini 93 orang nasabah tabungan Utama pada Bank Syariah Mega kota Bengkulu Teknik pengambilan sampel adalah teknik accidental sampling. Pengumpulan data menggunakan kuesioner dan metode analisis yang digunakan adalah regresi linier berganda, uji determinasi dan uji hipotesis. Hasil analisis regresi menunjukkan $Y=12,730+0,303 X_{1}+$ $0,410 X_{2}$, hal ini menggambarkan arah regresi yang positif, artinya terdapat pengaruh positif antara $X_{1}$ (kualitas pelayanan) dan $X_{2}$ (kepuasan nasabah) terhadap loyalitas nasabah (Y). Berarti bahwa apabila variabel kualitas pelayanan dan kepuasan nasabah meningkat maka akan meningkatkan loyalitas nasabah. Besarnya koefesien determinasi sebesar 0,399. Hal ini berarti bahwa $X_{1}$ (kualitas pelayanan) dan $X_{2}$ (kepuasan nasabah) berpengaruh terhadap loyalitas nasabah (Y) sebesar 39,9\% sedangkan sisanya 59,1\% dipengaruhi oleh variabel-variabel lainnya yang tidak diteliti dalam penelitian ini. Hasil uji t pada taraf signifikansi 0,05 menjelaskan bahwa secara parsial variabel kualitas pelayanan dan kepuasan nasabah mempunyai pengaruh yang signifikan terhadap variabel loyalitas nasabah Bank Mega Syariah Bengkulu. Hasil uji F pada taraf signifikansi 0,05 menjelaskan bahwa variabel kualitas pelayanan dan kepuasan nasabah memiliki pengaruh secara simultan (bersama-sama) terhadap loyalitas nasabah pada Bank Mega Syariah Bengkulu.

\section{ABSTRACT}

The purpose of this study is to determine the influence of service quality and customer satisfaction on customer loyalty at Bank Mega Syariah Bengkulu. The sample in this study was 93 main savings customers at Bank Mega Syariah, Bengkulu City. The sampling technique was accidental sampling technique. Data were collected using a questionnaire and analyzed through multiple linear regression, test of determination and hypothesis testing. The results of the regression analysis show $Y=12.730+0.303 \times 1+0.410 \times 2$, this shows a positive direction of regression, meaning that there is a positive influence between $X 1$ (service quality) and X2 (customer satisfaction) on customer loyalty $(Y)$. This means that if the variable service quality and customer satisfaction increases, it will increase customer loyalty. The 
coefficient of determination is 0.399 . This means that $X 1$ (service quality) and X2 (customer satisfaction) affect customer loyalty $(Y)$ by $39.9 \%$, while the remaining $59.1 \%$ is influenced by other variables not examined in this study. The results of the t test at the 0.05 significance level explain that partially the variable service quality and customer satisfaction have a significant influence on the customer loyalty variable of Bank Mega Syariah Bengkulu. The results of the $F$ test at the 0.05 significance level explain that the variables of service quality and customer satisfaction have a simultaneous (joint) influence on customer loyalty at Bank Mega Syariah Bengkulu.

\section{PENDAHULUAN}

Persaingan yang semakin ketat dan semakin berkembangnya ekspektasi pelanggan mendorong perusahaan untuk lebih memfokuskan pada upaya untuk mempertahankan pelanggan yang ada. Mempertahankan pasar yang ada melalui pengembangan loyalitas pelanggan merupakan tujuan strategik perusahaan untuk mempertahankan bisnis dan profit mereka dalam jangka panjang. Istilah loyalitas pelanggan menunjukkan pada kesetiaan pelanggan pada objek tertentu, seperti merek, produk, jasa atau toko. Konsep loyalitas pelanggan telah memberikan banyak perhatian dalam literatur pemasaran dan perilaku konsumen.

Loyalitas pelanggan memberikan dampak yang signifikan bagi profitabilitas perusahaan. Menurut Hurriyati (2016:129) loyalitas konsumen adalah komitmen konsumen bertahan secara mendalam untuk berlangganan kembali atau melakukan pembelian ulang. Pelanggan yang loyal kemungkinan akan menunjukkan sikap dan perilaku positif, seperti pembelian ulang produk/jasa yang sama dan rekomendasi positif yang dapat mempengaruhi pelanggan yang telah ada (customer loyal) dan menarik konsumen (pelanggan potensial) menjadi pelanggan dari perusahaan bisnis itu. Pentingnya loyalitas pelanggan sebagai tujuan utama bagi banyak perusahaan, para akademisi dan profesional pemasaran telah berusaha untuk menemukan loyalitas pelanggan. Begitu juga di dunia perbankan nasabah yang loyal akan ditunjukkan dengan menggunakan jasa perbankan tersebut secara berulang kali.

Kepuasan pelanggan dapat dikonseptualisasikan sebagai keseluruhan evaluasi pelanggan atas performance dari suatu penawaran (Tjiptono, 2014:88). Jika hasil evaluasi terhadap suatu produk/jasa yang dipilih memenuhi atau melampaui ekspektasinya, maka pelanggan tersebut kemungkinan akan menunjukkan sikap positif, dan memiliki keinginan untuk membeli/menggunakan kembali produk/jasa yang sama (repurchase intentions), dan keinginannya untuk bertindak sebagai referensi bagi orang lain (advocacy intentions). Intinya bahwa kepuasan pelanggan akan memainkan peran penting dalam menjelaskan alasan pelanggan dipandang loyal.

Secara teoritis ketika pelayanan yang diberikan mampu memenuhi atau melampaui pengharapan atau ekspetasi pelanggan maka pelanggan tersebut merasa puas (Lupiyoadi, 2017:214). Perusahaan perlu membangun sistem manajemen kualitas jasa untuk mengidentifikasi kesenjangan yang mungkin terjadi. Pentingnya meningkatkan kualitas pelayanan adalah untuk menciptakan kepuasan pelanggan dengan menjadikan pelanggan sebagai fokus utamanya. Kualitas pelayanan merupakan suatu bentuk penilaian konsumen terhadap tingkat layanan yang diterima (perceived services) dengan tingkat layanan yang diharapkan (expected service). Kualitas layanan difokuskan dalam pengukuran bentuk fisik (tangible), kehandalan (reliability), daya tanggap (responsiveness), jaminan (assurance), dan empati (empathy) (Lupiyoadi, 2017:216). Apabila kualitas pelayanan yang diberikan baik, maka konsumen akan memperoleh kepuasan atas produk/jasa dan cenderung melakukan pembelian ulang produk/jasa yang sama. Perusahaan yang tidak mengedepankan kualitas pelayanan dari produk/jasa yang ditawarkan akan mengakibatkan risiko tidak loyalnya pelanggan.

316 | Afif Fakhri Pahlevi; Suwarni; Nurzam; The Influence Of Service Quality.. 
Selain kualitas pelayanan, hal lain yang perlu diperhatikan adalah kepuasan nasabah. Kotler dan Keller (2014:177), menyatakan bahwa kepuasan adalah perasaan senang atau kecewa seseorang yang muncul setelah membandingan kinerja (atau hasil) produk yang dipikirkan terhadap kinerja (atau hasil) yang diharapan. Dengan kata lain, seseorang merasa puas apabila hasil yang didapat minimal mampu memenuhi harapannya sedangkan seseorang merasa tidak puas apabila hasil yang didapat tidak mampu memenuhi harapannya.

Bank Mega Syariah Bengkulu merupakan salah satu bank Syariah yang dipercaya oleh masyarakat, saat ini memiliki beberapa produk unggulan yang dapat bersaing baik dari segi teknologi maupun kedekatan kepada masyarakat. Adapun produk tabungan yang paling diandalkan dan memiliki jumlah nasabah terbesar adalah tabungan Utama .

Dari sistem pelayanan yang diberikan oleh Bank Mega Syariah Bengkulu apakah ada nasabah yang merasa puas, sehingga loyal terhadap bank ini sehingga nasabah menggunakan serta memanfaatkan kembali. Pelayanan yang diberikan oleh Bank Mega Syariah Bengkulu pada saat ini sudah dinilai sudah baik oleh konsumen, seperti adanya nomor antrian pada saat ingin menabung tabungan Utama, adanya pemberian asuransi jiwa bagi nasabah yang menabung tabungan Utama. Namun masih ada pelayanan yang masih kurang dari tabungan Utama, nasabah merasa keberatan dengan biaya administrasi yang harus dibayar setiap bulannya sebesar Rp. 5.000 untuk biaya administrasi tabungan dan Rp. 5.000 untuk biaya ATM sedangkan pada bank lain menawarkan tabungan tanpa biaya administrasi. Jika nasabah puas maka yang diharapkan oleh bank adalah merekomendasikan kerekannya yang lain untuk menggunakan jasa Bank Mega Syariah Bengkulu dan meningkatkan proporsi pembelanjaan layanan bank.

\section{LANDASAN TEORI}

\section{Bank}

Menurut Kasmir (2017:24) bank dikenal sebagai lemaga keuangan yang kegiatan utamanya menerima simpanan giro, tabungan dan deposito, bank juga dikenal sebagai tempat untuk meminjam uang. Kemudian pengertian bank menurut Undang-Undang Nomor 10 tahun 1998 bank merupakan badan usaha yang menghimpun dana dari masyarakat dalam bentuk simpanan dan menyalurkannya ke masyarakat dalam bentuk kredit atau bentuk-bentuk lainnya dalam rangka meningkatkan taraf hidup rakyat banyak.

Menurut Martono (2015:20) bank merupakan salah satu badan usah lembaga yang bertujuan memberikan kredit, baik dengan alat pembayaran sendiri, dengan uang ang diperolehnya dari orang lain dengan jalan mengedarkan alat-alat pembayaran baru berupa uang giral. Sedangkan pengertian bank menurut Undang-Undang nomor 7 tahun 1992 tetang perbankan bank adalah badan usaha yang menghimpun dana dari masyarakat dalam bentuk simpanan dan menyalurkannya kepada masyarakat dalam rangka meningkatkan taraf hidup rakyat banyak.

\section{Manajemen Pemasaran}

Manajemen pemasaran berasal dari dua kata yaitu manajemen dan pemasaran. Menurut Kotler dan Armstrong (2014:42) pemasaran adalah analisis, perencanaan, implementasi, dan pengendalian dari program-program yang dirancang untuk menciptakan, membangun, dan memelihara pertukaran yang menguntungkan dengan pembeli sasaran untuk mencapai tujuan perusahaan. Sedangakan manajemen adalah proses perencanaan (planning), pengorganisasian (organizing) penggerakan (actuating) dan pengawasan (controlling).

\section{Manajemen Pemasaran Bank}

Pemasaran perbankan adalah suatu proses untuk menciptakan dan mempertukarkan produk atau jasa bank yang ditujukan untuk memenuhi kebutuhan dan keinginan nasabah dengan cara 
memberikan kepuasan (Kasmir, 2016:63). Kegiatan pemasaran dalam perusahaan perbankan sangat penting karena melalui kegiatan ini produk maupun jasa yang ditawarkan oleh bank akan dapat lebih dikenal masyarakat. Selain itu kegiatan pemasaran ini dilakukan untuk menghadapi pesaing lain yang mempunyai bidang usaha yang sama Suatu kegiatan pemasaran pasti mempunyai tujuan tertentu yang harus dicapai sesuai dengan target yang telah ditetapkan, baik tujuan untuk jangka panjang maupun pendek.

\section{Kualitas Pelayanan}

Stemvelt (2015:210) menyatakan bahwa konsep kualitas layanan adalah suatu persepsi tentang revolusi kualitas secara menyeluruh yang terpikirkan dan menjadi suatu gagasan yang harus dirumuskan (formulasi) agar penerapannya (implementasi) dapat diuji kembali (evaluasi), untuk menjadi suatu proses yang dinamis, berlangsung, terus menerus dalam memenuhi kepuasan pelanggan. Apabila jasa yang diterima atau dirasakan sesuai dengan yang diharapkan, maka kualitas jasa dipersepsikan baik dan memuaskan

\section{METODE PENELITIAN}

\section{Regresi Linier Berganda}

Menurut Sugiyono (2016:275) regresi berganda digunakan untuk meramalkan bagaimana keadaan (naik turunnya) variabel dependen (kriterium), bila dua atau lebih variabel indenpenden sebagai faktor perdiktor dimanipulasi (dinaik turunkan nilainya). Adapun bentuk persamaan regresi linier berganda menurut Sugiyono (2016:151) adalah sebagai berikut :

$$
Y=a+b_{1} x_{1}+b_{2} X_{2}+b_{3} X_{3}+e
$$

Keterangan :

$\begin{array}{lll}\mathrm{Y} & = & \text { Loyalitas Nasabah } \\ \mathrm{X}_{1}= & \text { Kualitas Pelayanan } \\ \mathrm{X}_{2}= & \text { Kepuasan Nasabah } \\ \mathrm{a} & = & \text { Nilai konstanta } \\ \mathrm{e} & = & \text { erorr }\end{array}$

\section{Koefisien Determinasi (R2)}

Koefisien determinasi digunakan untuk mengukur seberapa jauh kemampuan model dalam menerangkan variabel dependen. Nilai koefesien determinasi adalah antara 0 dan 1. Nilai R2 yang kecil berarti kemampuan variabel - variabel independen dalam menerangkan variabel dependen sangat terbatas. Nilai yang mendekati 1 berarti variabel independen memberikan hampir semua informasi yang dibutuhkan untuk memprediksi variasi variabel dependen.

\section{Pengujian Hipotesis}

Uji t

Uji t pada dasarnya menunjukkan seberapa jauh pengaruh satu variabel bebas secara individual dalam menerangkan variasi variabel terikat.

\section{Uji F}

Uji F dilakukan untuk mengetahui pengaruh variabel bebas secara bersama-sama terhadap variabel terikat. Rumusan hipotesis yang diuji:. 


\section{HASIL DAN PEMBAHASAN}

\section{Analisis Regresi Linier Berganda}

Analisis regresi linier berganda digunakan untuk mengetahui besarnya pengaruh kualitas pelayanan dan kepuasan nasabah terhadap loyalitas nasabah pada Bank Mega Syariah Bengkulu. Hasil perhitungan regresi berganda dapat dilihat pada Tabel 1 berikut:

Tabel 1. Model Regresi Linier Berganda

\begin{tabular}{|c|c|c|c|c|c|c|}
\hline \multirow{2}{*}{\multicolumn{2}{|c|}{ Model }} & \multicolumn{2}{|c|}{ Unstandardized Coefficients } & \multirow{2}{*}{$\begin{array}{c}\begin{array}{c}\text { Standardized } \\
\text { Coefficients }\end{array} \\
\text { Beta } \\
\end{array}$} & \multirow[b]{2}{*}{$\mathrm{t}$} & \multirow[b]{2}{*}{ Sia. } \\
\hline & & $\mathrm{B}$ & Std. Error & & & \\
\hline \multirow[t]{3}{*}{1} & (Constant) & 12.730 & 3.719 & & 3.422 & .001 \\
\hline & Kualitas Pelayanan & 303 & .068 & .385 & 4.459 & .000 \\
\hline & Kepuasan Nasbah & 410 & .090 & .393 & 4.556 & .000 \\
\hline
\end{tabular}

a. Dependent Variable: Loyalitas Nasabah

Sumber: Hasil penelitian dan diolah, 2021

Berdasarkan Tabel 1 dapat dilihat persamaan regresi yang terbentuk adalah:

$$
Y=12,730+0,303 X_{1}+0,410 X_{2}+e
$$

Persamaan regresi tersebut dapat dijelaskan sebagai berikut :

a. Nilai konstanta 12,730 mempunyai arti bahwa apabila variabel Kualitas pelayanan $\left(X_{1}\right)$ dan kepuasan nasabah $\left(\mathrm{X}_{2}\right)$ dianggap sama dengan nol (0) maka variabel loyalitas nasabah $(\mathrm{Y})$ akan tetap sebesar 12,730 .

b. Pengaruh Kualitas pelayanan $\left(X_{1}\right)$ terhadap loyalitas nasabah $(Y)$

Nilai koefesien regresi variabel $X_{1}$ (Kualitas pelayanan) adalah sebesar 0,303 dengan asumsi apabila $X_{1}$ (Kualitas pelayanan) mengalami peningkatan sebesar satu-satuan, maka $Y$ (Loyalitas nasabah) juga akan mengalami peningkatan sebesar 0,303 kali.

c. Pengaruh Kepuasan nasabah $\left(\mathrm{X}_{2}\right)$ terhadap Loyalitas Nasabah $(\mathrm{Y})$

Nilai koefesien regresi variabel $X_{2}$ (kepuasan nasabah) adalah sebesar 0,410 dengan asumsi apabila $X_{2}$ (kepuasan nasabah) mengalami peningkatan sebesar satu-satuan maka $Y$ (loyalitas nasabah) akan mengalami peningkatan sebesar 0,410 kali.

Koefisien Determinasi $\left(\mathrm{R}^{2}\right)$

Tabel 2. Koefesien Determinasi

\begin{tabular}{|l|r|r|r|r|}
\hline \multicolumn{6}{|c|}{ Model Summary } \\
\hline Model & $\mathrm{R}$ & R Square & $\begin{array}{c}\text { Adjusted R } \\
\text { Square }\end{array}$ & $\begin{array}{c}\text { Std. Error of the } \\
\text { Estimate }\end{array}$ \\
\hline 1 & $.632^{\mathrm{a}}$ & .399 & .386 & 2.421 \\
\hline
\end{tabular}

a. Predictors: (Constant), Kepuasan Nasbah, Kualitas Pelayanan

Sumber: Penelitian dan diolah, 2021

Berdasarkan Berdasarkan Tabel2 untuk nilai koefesien determinasi menggunakan model $R$ square. Dari hasil perhitungan dengan menggunakan SPSS dapat diketahui nilai koefesien determinasi dari $R$ square yaitu sebesar 0,399. Hal ini berarti bahwa $X_{1}$ (kualitas pelayanan) dan $X_{2}$ (kepuasan nasabah) berpengaruh terhadap loyalitas nasabah ( $Y$ ) sebesar 39,9\% sedangkan sisanya 59,1\% dipengaruhi oleh variabel-variabel lainnya yang tidak diteliti dalam penelitian ini. 
p-ISSN 2798-0499 e-ISSN 2798-0502

Pengujian Hipotesis

Pengujian Hipotesis Secara Parsial (Uji t)

Pengujian hipotesis secara parsial atau uji t bertujuan untuk mengetahui tingkat pengaruh variable $X$ terhadap variable $Y$ secara terpisah atau masing-masing variable $X$ :

1. Variabel $X_{1}$ (Kualitas pelayanan)

Hasil pengujian untuk variabel $X_{1}$ (kualitas pelayanan) menunjukkan nilai signifikansi sebesar $0,000<0,05$. Karena nilai signifikansi lebih kecil dari 0,05, maka $\mathrm{H}_{0}$ ditolak dan $\mathrm{H}_{a}$ diterima. Artinya $\mathrm{X}_{1}$ (kualitas pelayanan) memiliki pengaruh yang signifikan terhadap loyalitas nasabah ( $\mathrm{Y}$ ) pada Bank Mega Syariah Bengkulu.

2. Variabel $\mathrm{X}_{2}$ (Kepuasan nasabah)

Hasil pengujian untuk variabel $X_{2}$ (Kepuasan nasabah) menunjukkan nilai signifikansi sebesar $0,000<0,05$. Karena nilai signifikansi lebih kecil dari 0,05, maka $\mathrm{H}_{0}$ ditolak dan $\mathrm{H}_{a}$ diterima. Artinya $\mathrm{X}_{2}$ (Kepuasan nasabah) memiliki pengaruh yang signifikan terhadap loyalitas nasabah (Y) pada Bank Mega Syariah Bengkulu.

Pengujian Hipotesis Secara Simultan (Uji F)

Dalam penelitian ini pengujian hipotesis dimaksudkan untuk mengukur pengaruh $\mathrm{X}_{1}$ (kualitas pelayanan) dan $\mathrm{X}_{2}$ (kepuasan nasabah) terhadap loyalitas nasabah ( $\mathrm{Y}$ ) secara bersama-sama maka digunakan uji F:

\begin{tabular}{|c|c|c|c|c|c|c|}
\hline \multicolumn{7}{|c|}{ ANOVA $^{a}$} \\
\hline \multicolumn{2}{|c|}{ Model } & Sum of Squares & $\mathrm{df}$ & Mean Square & $\mathrm{F}$ & Sig. \\
\hline \multirow[t]{3}{*}{1} & Rearession & 350.674 & 2 & 175.337 & 29.918 & .000 \\
\hline & Residual & 527.455 & 90 & 5.861 & & \\
\hline & Total & 878.129 & 92 & & & \\
\hline
\end{tabular}

a. Dependent Variable: Loyalitas Nasabah

Tabel 3. Hasil Uji F b. Predictors: (Constant), Kepuasan Nasbah, Kualitas Pelayanan

Sumber: Hasil penelitian dan diolah, 2021

Berdasarkan Tabel 3 diketahui nilai signifikansi sebesar 0,000 $<0,05$. Karena tingkat signifikansi di bawah 0,05 menunjukkan bahwa secara bersama-sama $X_{1}$ (kualitas pelayanan) dan $X_{2}$ (kepuasan nasabah) mempunyai pengaruh yang signifikan terhadap loyalitas nasabah (Y). Berdasarkan hasil uji simultan maka $\mathrm{H}_{0}$ ditolak dan $\mathrm{H}_{a}$ diterima, artinya antara variabel-variabel bebas yaitu $\mathrm{X}_{1}$ (kualitas pelayanan) dan $\mathrm{X}_{2}$ (kepuasan nasabah) mempunyai pengaruh yang signifikan secara bersama-sama terhadap loyalitas nasabah (Y) pada Bank Mega Syariah Bengkulu.

\section{Pengaruh Kualitas Pelayanan Terhadap Loyalitas Nasabah}

Hasil pengujian pada penelitian ini menunjukkan bahwa terdapat pengaruh yang signifikan antara kualitas pelayanan terhadap loyalitas nasabah. Hal ini menggambarkan bahwa semakin meningkat kualitas pelayanan yang diberikan oleh Bank Mega Syariah Bengkulu terhadap nasabah maka loyalitas nasabah akan semakin meningkat. artinya kualitas pelayanan yang diberikan oleh karyawan Bank Mega Syariah Bengkulu mampu meningkatkan loyalitas nasabah.

Kualitas pelayanan yang disediakan oleh Bank Mega Syariah Bengkulu dapat dilihat dari pelayanan yang ramah dan sopan yang diberikan oleh karyawan kepada nasabah, ruang tunggu yang nyaman, sistem antrian yang teratur. Selain itu karyawan juga memberikan pelayanan dengan cepat kepada nasabah pada saat nasabah membutuhkannya.

Hasil penelitian ini sesuai dengan pendapat Assauri (2014:78) menyatakan para pelanggan akan mencari produk berupa barang atau jasa dari perusahaan yang dapat memberikan pelayanan yang terbaik kepadanya. Kualitas merupakan inti kelangsungan hidup sebuah perusahaan, persaingan yang semakin ketat akhir-akhir ini menuntut sebuah lembaga penyedia jasa/layanan untuk selalu memanjakan konsumen/ dengan memberikan pelayanann terbaik. Kualitas pelayanann merupakan komponen penting dalam persepsi nasabah, juga sangat penting dalam pengaruhnya 320 | Afif Fakhri Pahlevi; Suwarni; Nurzam; The Influence Of Service Quality.. 
terhadap kepuasan nasabah. Semakin baik kualitas maka jasa yang diberikan akan semakin baik pula citra jasa tersebut dimata nasabah.

\section{Pengaruh Kepuasan Nasabah Terhadap Loyalitas Nasabah}

Hasil pengujian pada penelitian ini menunjukkan bahwa terdapat pengaruh yang signifikan antara kepuasan nasabah terhadap loyalitas nasabah. Hal ini menggambarkan bahwa semakin meningkat kepuasan yang dirasakan oleh nasabah Bank Mega Syariah Bengkulu maka akan meningkatkan loyalitas nasabah. Kepuasan yang dirasakan oleh nasabah akan membuat nasabah tetap setia menjadi nasabah Bank mega Syariah Bengkulu.

Kepuasan nasabah tabungan yang ditawarkan oleh Bank Mega Syariah Bengkulu memiliki tingkat suku bunga yang bersaing sehingga nasabah tertarik untuk menabung sehingga nasabah merasa puas dengan tingkat keuntungan yang diberikan oleh Bank Mega Syariah Bengkulu. Selain itu, Bank Mega Syariah Bengkulu juga memberikan pelayanan ATM yang dapat memudahkan nasabah untuk melakukan transaksi perbankan dan dilengkapi dengan fitur-fitur yang lengkap seperti penarikan uang, transfer, pembelian dan pembayaran sesuai dengan kebutuhan nasabah. Kemudahan lain yang diberikan oleh Bank Mega Syariah Bengkulu adalah dengan biaya administrasi yang rendah sehingga nasabah tertarik untuk menabungkan uangnya di Bank Mega Syariah Bengkulu dan selalu setia menggunakan Bank Mega Syariah Bengkulu untuk semua transaksi perbankannya.

Hasil penelitian ini sejalan dengan teori yang disampaikan oleh Lupiyoadi (2016:194) yang menyatakan pada dasarnya kepuasan dan ketidakpuasan konsumen atas produk atau jasa akan berpengaruh pada pola perilaku selanjutnya. Apabila konsumen merasa puas, maka dia akan menunjukkan besarnya kemungkinan untuk kembali menggunakan produk atau jasa yang sama. Konsumen yang puas juga cenderung akan memberikan referensi yang baik terhadap produk atau jasa kepada orang lain.

\section{KESIMPULAN DAN SARAN}

\section{Kesimpulan}

1. Hasil analisis regresi menunjukkan $Y=12,730+0,303 \times 1+0,410 \times 2+e$, hal ini menggambarkan arah regresi yang positif, artinya terdapat pengaruh positif antara X1 (kualitas pelayanan) dan X2 (kepuasan nasabah) terhadap loyalitas nasabah (Y). Berarti bahwa apabila variabel kualitas pelayanan dan kepuasan nasabah meningkat maka akan meningkatkan loyalitas nasabah.

2. Besarnya koefesien determinasi sebesar 0,399. Hal ini berarti bahwa X1 (kualitas pelayanan) dan X2 (kepuasan nasabah) berpengaruh terhadap loyalitas nasabah (Y) sebesar 39,9\% sedangkan sisanya 59,1\% dipengaruhi oleh variabel-variabel lainnya yang tidak diteliti dalam penelitian ini.

3. Hasil uji t pada taraf signifikansi 0,05 menjelaskan bahwa secara parsial variabel kualitas pelayanan dan kepuasan nasabah mempunyai pengaruh yang signifikan terhadap variabel loyalitas nasabah Bank Mega Syariah Bengkulu.

4. Hasil uji $\mathrm{F}$ pada taraf signifikansi 0,05 menjelaskan bahwa variabel kualitas pelayanan dan kepuasan nasabah memiliki pengaruh secara simultan (bersama-sama) terhadap loyalitas nasabah pada Bank Mega Syariah Bengkulu.

\section{Saran}

1. Kepada Bank Mega Syariah Bengkulu untuk mempertahankan kualias pelayanan yang dinilai sudah baik oleh nasabah.

2. Kepada Bank Mega Syariah Bengkulu untuk memerikan bonus kepada nasabah yang rajin menabung agar nasabah termotivasi untuk lebih meningkatkan saldo tabungannya dan menjadi nasabah yang setia. 
p-ISSN 2798-0499 e-ISSN 2798-0502

\section{DAFTAR PUSTAKA}

Astati. 2017. Analisis Pelayanan Jasa dan Kepuasan konsumen pada Usaha Jasa Service Mobil Saf Bengkulu. FE-UNIVED: Bengkulu

Djumhana, Muhammad. 2017. Hukum Perbankan di Indonesia, Citra Aditya Bakti: Bandung

Hasan, Ali. 2014. Marketing. Media Utama: Yogyakarta.

Hurriyati, Ratih. 2016. Bauran Pemasaran dan Loyalitas Konsumen. Alfabeta. Bandung

Kasmir, 2016. Bank dan Lembaga Keuangan Lainnya. Jakarta : PT. Raja Grafindo Persada

Kotler dan Amstrong. 2014. Prinsip-prinsip Marketing. Edisi Ketujuh. Penerbit Salemba Empat. Jakarta.

Kotler, Philip. 2015. Manajemen Pemasaran. : Erlangga: Jakarta

Lovelock, Cristhoper H dan Lauren K. Wright. 2014. Manajemen Pemasaran Jasa. Alih bahasa Agus Widyantoro. Cetakan Kedua. Indeks: Jakarta

Lupiyoadi, Rambat. 2017. Manajemen Pemasaran Jasa Berbasis Kompetensi. Jakarta: Salemba Empat

Mitior. 2017. Hubungan Pelayanan dengan Kepuasan Pelanggan Pada Bengkel Candera Motor di Kaur Utara Kabupaten Kaur. Skripsi. Universitas Dehasen Bengkulu

Rahardjo, Budi. 2015. Laporan Keuangan Perusahaan. Yogyakarta : UGM Press

Sastradipoera, Komaruddin. 2015. Manejemen Sumber daya Manusia: Suatu Pendekatan Fungsi Operatif Edisi I. Penerbit Kappa-Sigma: Bandung

Schiffman \& Kanuk. 2015. Perilaku Konsumen. dialih bahasakan oleh Zulkifli Kasip. Edisi Ketujuh. Penerbit PT. Indexs.

Shofie, Yusuf. 2017. Perlindungan Konsumen dan Instrumen-Instrumen Hukumnya, Citra Aditya Bakti: Bandung

Stemvelt, Robert C.. 2015. Perception of Service Quality. Alih Bahasa oleh Purwoko. Allyn and Bacon. Massachusetts.

Sugiyono. 2017. Metode penelitian pendidikan: pendekatan kuantitatif. kualitatif. dan $R$ \& D. Alfabeta: Bandung

Sunyoto, Danang. 2017. Konsep Dasar Riset Pemasaran Dan Prilaku Konsumen. Cetakan Ke empat. Andi. Yogyakarta.

Susena, K. C., Irwanto, T., \& Priandi, E. (2019). FAKTOR-FAKTOR YANG MEMPENGARUHI KEPUTUSAN NASABAH DALAM MEMILIH PEMBIAYAAN GRIYA IB HASANAH DI PT. BANK BNI SYARIAH KANTOR CABANG BENGKULU. EKOMBIS REVIEW: Jurnal IImiah Ekonomi dan Bisnis, 7(2).

Sutisna. 2014. Perilaku Konsumen \& Komunikasi Pemasaran . Rosdakarya: Bandung

Swastha, Basu. 2017. Manajemen Pemasaran.: Universitas Terbuka: Tanggerang Selatan

Tjiptono, Fandy. 2014. Manajemen Pelayanan Jasa. Penerbit Andi. Yogyakarta

Undang-Undang No. 10 Tahun 1998 tentang Perubahan Atas Undang-Undang No. 7 Tahun 1992 tentang Perbankan

Undang-Undang No. 24 Tahun 2004 tentang Lembaga Penjamin Simpanan

Usmara. 2014. Strategi Baru Manajemen Pemasaran. Amoro Book: Yogyakarta

Yong, C.Z.. Yun. Y.W.. Loh. L.. 2014. The Quest for Global Quality. Alih Bahasa oleh Sutanto. Pustaka Delapratasa. Jakarta.

322 | Afif Fakhri Pahlevi; Suwarni; Nurzam; The Influence Of Service Quality.. 